\title{
MASS COMMUNICATIONS AND THE FIRST AMENDMENT: AN OVERVIEW
}

\author{
L. A. Powe, Jr.* \\ I

\section{INTRODUCTION}

Mass communications issues have traditionally been slighted or ignored in first amendment writings, and, when recognized, they have been treated as a subset of the larger problem of freedom of expression. In large part, this stems from the instant establishment of the dominant first amendment paradigm of the lonely political dissenter. It was also assisted by the lack of significant newspaper cases (even the Los Angeles Times-Mirror was attached to Harry Bridges's claim') and the initial inability to perceive movies, then radio and television, as being integral to the first amendment. ${ }^{2}$ Yet like it or not, mass communications have become the essential component of the way we choose our elected representatives and establish the nation's agendas.

When the typical speech cases involved reds, pinks, blacks, and the likes of Fanny Hill, it was all too easy for academics to ignore the harm that expression may cause. Commies did not look as ferocious to many scholars after the fall of Joseph McCarthy as they did to Chief Justice Vinson during the Korean War. Any harms flowing from civil rights speech were not harms at all, but the necessary benefits of acquiring a just order. And obscenity, the nonpolitical triad of the first amendment docket, was, during its formative period, very tame stuff, being countered by laws and attitudes that dated from the Victorian era; believing in harms from its existence had all the credibility that fundamentalists could impart. Overall, the cases offered a gloss on the first amendment suggesting, as Brandeis had, ${ }^{3}$ that more speech was always better and that the claims of societal harm were the rear guard professions of those fighting to preserve the remnants of the Taft Wing of the Republican Party (as Douglas came close to doing). ${ }^{4}$

The problem with that picture is the trivialization of the first amendment, whose purpose then becomes largely to prevent the misbalancing of relevant interests. It should-and does-mean more. Thanks in no small part to Fred

Copyright $\odot 1992$ by Law and Contemporary Problems

* Anne Green Regents Chair, School of Law and Department of Government, The University of Texas.

1. Bridges v Calif., together with Times-Mirror Co. v Superior Court of Calif., 314 US 252 (1941).

2. Mutual Film Corp. v Ohio Industrial Comm'n, 236 US 230 (1915). See also L. A. Powe, Jr., American Broadcasting and the First Amendment 13-30 (U California Press, 1987).

3. Whitney $v$ California, 274 US 357, 377 (1927)(Brandeis dissenting, joined by Holmes).

4. Brandenburg v Ohio, 395 US 444, 454 (1969)(Douglas concurring). 
Schauer's many writings ${ }^{5}$ and then to the anguished cries of victims of hate speech, ${ }^{6}$ virtually everyone writing today in the first amendment area understands, as their academic elders seemed not to, that speech hurts. Because speech may inflict genuine harm, there is a legitimate impetus toward efforts at redress.

No one dealing with issues of mass communications could doubt that speech at times causes harm. When CBS causes a distinguished military veteran, such as General William Westmoreland, to assure audiences that he is not a traitor, ${ }^{7}$ or when the Miami Herald drives the front-running Democratic presidential contender in 1988, Gary Hart, out of contention for the presidency, ${ }^{8}$ there can be no doubt that words have real consequences. The media are powerful speakers-the largest distributors (if not contributors) to the marketplace of ideas-and they reach audiences beyond the dreams of a Debs, ${ }^{9}$ Abrams, ${ }^{10}$ Gitlow, ${ }^{11}$ or Cohen. ${ }^{12}$ Whatever the overworked term means, major newspapers and broadcasters appear to possess tremendous "power." Now that academics in the speech area have taken account of expression's genuine harms and may soon be forced to deal with issues of power as well, the analogies offered by mass communications cases to these new issues ought to make them look a little less like an insignificant subset of the first amendment's concerns.

Instead of perceiving mass communications as a subset of freedom of speech, I am going to keep company with the Framers (who came to the protection of freedom of speech well after freedom of the press) ${ }^{13}$ and assume the centrality of the press. This makes present-day factual sense-flagburners to the contrary notwithstanding-because modern politics cannot be meaningfully discussed without mass marketing. Additionally, it makes theoretical sense because, however distasteful it is, some speakers have more influence, rightly or wrongly, in the marketplace. Because of both power and potential harm, the mass communications cases (as opposed to other speech

5. Frederick F. Schauer, Free Speech: A Philosophical Inquiry (Cambridge U Press, 1982); Frederick F. Schauer, The Second Best First Amendment, 31 Wm \& Mary L Rev 1 (1989); Frederick F. Schauer, Must Speech Be Special?, 78 Nw U L Rev 1284 (1984).

6. See, for example Mari J. Matsuda, Public Response to Racial Speech: Considering the Victim 's Story, 87 Mich L Rev 2320 (1989).

7. L. A. Powe, Jr., The Fourth Estate and the Constitution: Freedom of the Press in America 137 (U California Press, 1991).

8. Larry Sabato, Feeding Frenzy 76-79 (Free Press, 1991).

9. Debs $v$ United States, 249 US 211 (1919)(convicted for attempting to cause insubordination by a speech on socialism at an outdoor rally expressing opposition to Prussian militarism in a way that might be thought to include the United States).

10. Abrams v United States, 250 US 616 (1919)(convicted for advocating curtailment of military production with intent to harm the United States in the war against Germany by advocating a strike because of the United States's invasion of Russia).

11. Gillow v New York, 268 US 652 (1925)(convicted for advocating communism because a revolutionary spark at the present could kindle a sweeping conflagration sometime in the future).

12. Cohen v California, 403 US 15 (1971)(jacket emblazoned with "Fuck the Draft" constitutionally protected in a courthouse; those offended may avert their eyes).

13. Powe, The Fourth Estate at 42-50 (cited in note 7); David A. Anderson, Origins of the Press Clause, 30 UCLA L Rev 455, 464-65 (1983). 
cases) have an interesting split between the regulation of harm and the regulation of the marketplace, a split that helps clarify the dilemmas facing first amendment theorists. ${ }^{14}$

\section{II}

\section{The Regulation of Harms}

Although it is not entirely accurate, harms from speech, consistent with the mode of expression, generally tend to be more specific, while harms from mass communications, again consistent with the mode of expression, tend to be more general. In the former, harm is typically demonstrable; either the words have wounded the audience or caused the audience to take action against someone or something. ${ }^{15}$ Cantwell's attack on Catholicism either caused or did not cause a breach of the peace by the addressee. ${ }^{16}$ In mass communications cases, by contrast, the harm is likely to be shared more universally, as when military secrets are published. Libel and privacy are obvious exceptions, but even there the concern over the torts would be significantly lessened if the harm to the body politic were removed.

\section{A. National Security}

For all the talk about national security and the harm a serious breach could inflict, the United States has never adopted anything similar to Great Britain's Official Secrets Act, which criminalizes the disclosure of classified information. ${ }^{17}$ Instead, there are only a few statutes and a few litigated cases that deal with the public disclosure of sensitive information. ${ }^{18}$ Describing the statutes, former CIA Director William Colby stated that Congress had "drawn a line between espionage for a foreign power and simple disclosure of

14. The categories of harm and the balancing of the market are not airtight, of course. Punitive damages in libel cases may have less to do with redressing harm than redressing market power. Jerome A. Barron, Punitive Damages in Libel Cases-First Amendment Equalizer?, 47 Wash \& Lee L Rev 105 (1990). The radical feminist attack on pornography argues that pornography creates and reinforces the dominant viewpoint of patriarchy. Catherine A. Mackinnon, Feminism Unmodified: Discourses on Life and Law 155-56 (Harvard U Press, 1987). Indeed, the lack of fit between typical harm and the sweep of the definition of pornography stems precisely from a desire to redress the imbalance in the marketplace by silencing the predominant voice of male dominance. Michigan's campaign finance statute was justified in terms of a harm, a newly created definition of corruption, rather than the equalitarian benefits of leveling down. The World War I Espionage Act cases, Schenk $v$ United States, 249 US 47 (1919); Frohwerk v United States, 249 US 204 (1919); Debs, 249 US 211 ; and Abrams, 250 US 616, could be rewritten in terms of the speakers' efforts to counter the market power of the Creel Committee's propaganda machinery, Mark G. Yudof, When Government Speaks: Politics, Law, and Government Expression in America 62-64 (U California Press, 1983); Stephen Vaughn, Holding Fast the Inner Lines: Democracy, Nationalism, and the Committee on Public Information (U North Carolina Press, 1980), but there is little reason to do so. The Court has worked with the harm principle for almost a century and is quite familiar with its boundaries even as the paradigm cases have receded into insignificance.

15. Dennis v United States, 341 US 494, 568 (1951)(Jackson concurring).

16. Cantwell $v$ Connecticut, 310 US 296 (1940).

17. Powe, The Fourth Estate at 173 (cited in note 7).

18. See, for example, Atomic Energy Act of 1954, 42 USC. $\S \S 2014(y)(1), 2274,2277$ (1989); Intelligence Identities Protection Act of 1982, 50 USC $\$ 421$ (1989); United States v Morison, 844 F2d 1057 (4th Cir 1988). 
our foreign policy and defense secrets, and decided that the latter problems are an acceptable cost of the kind of society we prefer." 19

Colby's observation should be tempered slightly. First, there is the problem of conversion of government property; section 641 of the United States Criminal Code criminalizes the unauthorized taking of anything "of value." 20 On its face this statute appears extremely broad. Second, the line that Colby articulated is reflected in section 794 of the Espionage Act, ${ }^{21}$ but its companion, section 793, goes considerably further by prohibiting disclosure of covered information to unauthorized persons. ${ }^{22}$ While this makes section 793 sound like an Official Secrets Act, it is not because it is aimed at the source, not at those who subsequently publish the information. Third, there are regulations, specifically those promulgated by the CIA, that preclude those persons with access to classified information from disclosing such information without permission. ${ }^{23}$ Behind this meager statutory and regulatory authority, however, there is little else: perhaps the possibility of an injunction prior to publication, and, in extreme cases, the threat of treason.

National security has often been seen as the only time the government is likely to breach successfully the first amendment barrier against prior restraints. While this is not entirely accurate, ${ }^{24}$ there is no doubt that the national security exception to prior restraints is the most interesting facet of the prior restraints doctrine. The exception, created in dicta in Near $v$. Minnesota ${ }^{25}$ was, of course, put to issue in the leak of the forty-seven volume Pentagon Papers, ${ }^{26}$ but the Court rather blandly found that the steep showing of immediate harm required to justify an injunction had not been met. In contrast, when Howard Morland used his own ingenuity and unclassified sources to explain how an $\mathrm{H}$-bomb worked, a federal district judge, noting the extreme dangers of allowing certain third world countries to acquire this information, did issue an injunction. ${ }^{27}$ Yet there was no claim that any "immediate" harm would occur, as the Pentagon Papers Cases had required. As with Dennis $v$. United States, ${ }^{28}$ the trial judge found that the gravity of the harm could push the requirement of immediacy into the background.

The H-Bomb case was then mooted when an alternative source published the same information. ${ }^{29}$ That outcome underscored a reality of the problem

19. Powe, The Fourth Estate at 173 (cited in note 7).

20. 18 USC. $\$ 641$ (1989) (conversion).

21. Id $\S 794$ (disclosure of sensitive information to foreign nations).

22. Id $\S 793$ (disclosure of such information to unauthorized persons).

23. See Snepp v United States, 444 US 507 (1980).

24. Powe, The Fourth Estate at 149-50, 161-63 (cited in note 7).

25. 283 US 697,716 (1931)(“[L]iberty of the press, historically considered and taken up by the Federal Constitution, has meant, principally although not exclusively, immunity from previous restraints or censorship.").

26. New York Times y United States, 403 US 713 (1971).

27. United States $v$ The Progressive, Inc., 467 F Supp 990, 997 (WD Wis 1979) (holding prior restraint appropriate because a single $\mathrm{H}$-bomb even in the future would ruin your whole day).

28. 341 US 494; see also L. A. Powe, Jr., The H-Bomb Injunction, 61 U Colo L Rev 55, 60 (1990).

29. United States $v$ The Progressive, Inc., 610 F2d 819 (7th Cir 1979)(dismissing the publisher's appeal without a published opinion). 
of injunctive relief to prevent a supposed national security breach: copying machines and computer discs have made prior restraints virtually obsolete because the materials will almost always show up somewhere else. The injunction itself places such an imperative on someone publishing the now illicit-and (rightly or wrongly) tantalizing - material that one can rest assured that it will surface. While this new reality is not yet reflected in the prior restraints doctrine, the government necessarily will be forced to rely on criminal sanctions if it wishes to deter publication in the future. ${ }^{30}$

Aside from prior restraints, criminal law on publications remains muddled indeed. Despite upholding the press in every single "privacy" case and in other, noncopyright contexts where it has published truthful information noncoercively obtained from government sources, the Court has avoided sweeping rules and assumed that somewhere down the line may lie a situation where the press ought not publish. ${ }^{31}$ Maybe the Court, sub silentio, does have a rule protecting the press in noncoercive acquisition cases, but not delineating the rule leaves the potential deterrent of criminal penalties hanging as a very last incentive to encourage good citizenship (as the New York Times displayed in its choices of what not to publish out of the Pentagon Papers). ${ }^{32}$ Justice Stewart, if not the Court, explicitly suggested this approach, ${ }^{33}$ and past practice indicates that it will likely take a blockbuster disclosure before sanctions against the press, rather than the actual source, could be constitutionally permissible. ${ }^{34}$

Surprising as it may seem, de facto press immunity receives support from both recent legislation and prosecutorial practices. The Intelligence Identities Protection Act of 1982 covers anyone, including the press, who, "with reason to believe that such activities would impair or impede the foreign intelligence activities of the United States, discloses any information that identifies an individual as a covert agent."'35 However, it includes an important proviso: such disclosures must evince a "pattern of activities intended to identify or expose covert agents." 36 The proviso thus appears to limit the operation of the law to publications such as the "Covert Action Information Bulletin," 37 and thereby ignore the regular press.

It has been almost twenty years and five administrations since Branzburg $v$. Hayes ${ }^{38}$ held that there is no general first amendment privilege for reporters who wish to protect their confidential sources. Yet there has not been a single

30. Powe, 61 U Colo L Rev at 69-70 (cited in note 28).

31. See, for example, Florida Star $v$ B.J.F., 491 US 524, 530 (1989).

32. The supposedly harmful material cited in the government's secret brief has never been revealed.

33. Potter Stewart, "Or of the Press," 26 Hastings L J 631, 635-36 (1975).

34. Powe, The Fourth Estate at 177 (cited in note 7).

35. Intelligence Identities Protection Act of 1982, $\$ 1$, codified at 50 USC $\$ 421$ (c).

36. Id.

37. This was Philip Agee's vehicle for blowing the cover of CIA agents in the field. See note 42 and accompanying text.

38. 408 US 665 (1972). 
subpoena to trace an inside-the-Beltway leak of information, ${ }^{39}$ a fact that, when contrasted with the press's fears that Branzburg would result in sources drying up, ${ }^{40}$ speaks volumes about the realization by all involved that information for public debate is essential-even when the information is highly classified. Nor has any administration indicted the press for disclosing sensitive information-not even the Progressive, whose $\mathrm{H}$-bomb article and accompanying diagram failed to match the discretion exhibited by the New York Times when they published the Pentagon Papers. By contrast, though, Daniel Ellsberg was indicted for leaking the Pentagon Papers; Samuel Loring Morison was convicted for leaking a satellite photo and defense briefing to Jane's Defense Weekly; ${ }^{41}$ and Philip Agee lost his passport after he persistently identified CIA agents in the field. ${ }^{42}$

Few observers would argue, and no court would likely agree, that there is a wholesale first amendment right to disclose secret information. Yet disclosure-leaking information-is a way of life in the nation's capital, and there seems to be general agreement that without leaks it would be impossible to uilderstand modern government (especially diplomacy and national security). ${ }^{43}$ Sometimes the leak is designed to kill a program; naturally, the disclosure thereby gains the enmity of an administration that wishes to pursue the piogram without the negative information in the public arena. ${ }^{44}$ But a large number of leaks are a matter of official policy (and if official enough, not a "leak" in the pejorative sense, but a purposeful and legitimate disclosure). For example, as the estimated final cost of the B-2 Stealth Bomber rocketed upward, the Reagan Administration and the Pentagon found that there was reluctance to purchase any airplane that cost over a half-billion dollars per plane. To create support, the B-2 almost literally overnight went from the most highly classified weapons program to the subject of photographs on newspapers' front pages. ${ }^{45}$

The operations of all three branches of government have authorized the press to disclose the information it acquires: Congress, both by what it has not passed and by the lines drawn in the statutes it has passed, the executive, by the tradition of not subpoenaing reporters and not prosecuting newspapers for security leaks, and the judiciary, by declining prior restraints and protecting the press when the issue has been disclosure of information. The operative outcomes can be explained in terms of a very particularistic view of causation. It is the leaker, not the reporter or the newspaper, who causes any harm to the national interest. While such a view of causation is

39. Powe, The Fourth Estate at 184 (cited in note 7). The frivolous and futile effort to obtain the name of the Anita Hill leaker from the press occurred as this article went to press.

40. Theodore H. White, Why the Jailing of Myron Farber "Terrifies Me." NY Times Magazine 27 (Nov 28, 1978); Monica Langley \& Lee Levine, "Branzburg" Revisited: Confidential Sources and First Amendment Values, 57 Geo Wash L Rev 13 (1988).

41. Morison, 844 F2d 1057.

42. Haig $v$ Agee, 453 US 280 (1980)

43. Powe, The Fourth Estate at 177-78 (cited in note 7).

44. See generally Martin Linsky, Impact (W.W. Norton, 1986).

45. Powe, The Fourth Estate at 171 (cited in note 7). 
unlikely to be found in modern common law analysis, it is a fairly standard first amendment analysis: ${ }^{46}$ the Court has simply disengaged speech from subsequent (punishable) action. In the mass communications area, the same process is at work in reverse. The harm is treated as occurring first and the publication is protected by treating it as separate and after the point of actionable harm.

Laurence Tribe sees this area as operating under a "rough 'law of the jungle." "47 The leaker is, if necessary, fed to the animals so that the stronger newspaper will survive. Everyone in this jungle from leaker to president understands that sensitive information will enter the public arena, that it may (but probably does not) harm the national interest, but that without the information the government has too many ways to manipulate debate to achieve its own ends. The Court's narrow view of causation, focusing on the initial disclosure rather than its mass distribution, pinpoints a culprit who can be punished with the minimum damage to public debate and the easiest explanation in first amendment terms. After all, it is vastly easier to understand that publishing information in your possession is an exercise of freedom of the press than to grasp that either pilfering documents or disclosing confidences in breach of positions of trust is an exercise of freedom of speech. By focusing on the leaker and not the press, the Court simultaneously authorizes a more informed public discussion, minimizes any chill, and still leaves the opportunity to assign blame. With the end of the Cold War, a preliminary assessment would appear to be that the Court's de facto balance worked reasonably well.

\section{B. Fair Administration of Justice}

At least some of the foregoing was placed at issue by the temporary restraining order issued by a federal judge to prevent the Cable News Network ("CNN") from airing tapes it had been given containing telephone conversations between Manuel Noriega and his attorneys. ${ }^{48}$ While trial judges have occasionally been unduly sensitive to published reports about cases they are handling, the Supreme Court's unblemished record from Bridges and Times-Mirror through Nebraska Press Association v. Stuart ${ }^{49}$ gives trial judges no leeway (albeit, as in Noriega, the Court did not intervene at the earliest stages of this litigation). The only times the press has been found to have prejudiced a defendant's sixth amendment right to a fair trial have been where the trial judges mistakenly have turned the courtroom over to the media, as in Sheppard ${ }^{50}$ and Estes. ${ }^{51}$ Otherwise, it is not too difficult to find twelve jury members who have never heard of the defendant, be he Oliver

46. Jack Balkin, The Rhetoric of Responsibility, 76 Va L Rev 197, 254-61 (1990).

47. Laurence H. Tribe, American Constitutional Law 965 (Foundation Press, 2d ed 1988).

48. CNN Gives Up Noriega Tapes to Federal Court in Florida, NY Times B9 col 1 (Nov 20, 1990).

49. 427 US 539 (1976).

50. Sheppard v Maxwell, 384 US 333 (1966).

51. Estes v Texas, 381 US 532 (1966). 
North or Manuel Noriega. The right to a fair trial therefore, for the most part, cannot be prejudiced by publication.

The real alleged harm from CNN airing the Noriega tapes was the breach of attorney-client privilege. While the airing may do more than prejudice potential jurors, it is still speculative because (1) Noriega might be acquitted; (2) prosecutors might successfully isolate themselves from the disclosures; (3) the taped discussions might not have anything to do with what would eventually occur at trial; or (4) the tapes may discuss only things the government already knows, such as the identity of government witnesses. To be sure, the judge needed the temporary restraint to acquire a less speculative estimate of harm, but given the likely ambiguity of the harm, the Supreme Court's prior restraint jurisprudence ought to have precluded even the temporary order that let the trial judge review the tapes and decide for himself. 52

After the judge reviewed the tapes, he lifted his order and ended the unfortunate episode. ${ }^{53}$ His initial risk aversion was understandable: Noriega's trial is the biggest of his career. Nevertheless, CNN had acquired the tapes legally, did not prejudice the case, and added information to a continuing debate about the consequences of invading Panama. Those facts highlight why editors, rather than judges, should decide whether to publish.

\section{Libel}

Libel, once thought by all but Harry Kalven to raise no constitutional issues, ${ }^{54}$ has been an exceptionally active area of constitutional debate for the past quarter century. With a $\$ 500,000$ award to Montgomery Commissioner L. B. Sullivan ${ }^{55}$ and millions of dollars more at stake in similar suits, Alabama had apparently found a method to counterattack northern pressure, one that carried with it the potential to bankrupt the then less financially secure New York Times. 56 The Court countered with its requirement that before a public official could prevail in a libel action, the official must show that the press published the information either knowing it was false or with reckless disregard of its validity. Despite its promise to balance successfully the interests of reputation against the chilling effect that civil liability imposes on the press, over the years the law of defamation has become an ever more intricate maze of rules that accomplish none of its objectives. Like the Holy Roman Empire, which many have observed was neither holy, Roman, nor an empire, the constitutional rules of libel protect neither reputation, the press, nor the public's interest in receiving accurate information.

52. US v Noriega, 917 F2d 1543 (11th Cir 1990), cert denied sub nom Cable News Network v Noriega, $111 \mathrm{~S}$ Ct 451 (1990).

53. LS v Noriega, 752 F Supp 1037 (SD Fla 1990).

54. Harry Kalven, Jr., The New York Times Case: A Note on the "Central Meaning of the First Amendment," 1964 S Ct Rev 191, 192 n4 (citing his otherwise unavailable mid-1950s suggestion that libel involves constitutional issues).

55. New York Times v Sullivan, 376 US 254 (1964).

56. James C. Goodale, Is the Public "Getting Even" with the Press in Libel Cases?, 188 NY L.J 1 (1982). 
Libel's best known feature may be dividing defamed plaintiffs into two classes, public and private figures, with only the former having to meet the New York Times actual malice standard. ${ }^{57}$ Yet that has had little impact on litigation, because private figures also need to show actual malice to recover punitive damages, the practical key to finding an attorney willing to take the case on a contingent fee. At trial, the court rules regarding libel attempt to minimize jury discretion. The plaintiff bears the burden of proving falsity, ${ }^{58}$ and those statements that "cannot reasonably [be] interpreted as stating actual facts" are fully protected.59 There is strict appellate supervision of the evidence unmatched in any other area of law. ${ }^{60}$

In operation, an overwhelming number of libel suits are disposed of prior to trial; therefore, a plaintiff is never granted a forum in which to show that the defamatory statements were in fact false. ${ }^{61}$ If the case goes to a jury, the odds shift heavily to the plaintiff, although damage awards are likely to be set aside either by the trial judge or appellate court. ${ }^{62}$ Rarely do plaintiffs successfully overcome all the built-in protections designed to protect the press. ${ }^{63}$ As a result, the rules underprotect reputation, do not provide the public with an opportunity to know the truth about injured plaintiffs, and, in all likelihood, deter at least some individuals from entering the public arena where, they fear, rightly or wrongly, becoming fair game for unfair media. ${ }^{64}$ Nevertheless, current law also fails to serve the interests of the press. A wholly unanticipated aspect of New York Times was the way it turned the libel trial away from the statements of the defendant about the plaintiff, to a scrutiny of how the press put the story together. The dynamics of a trial focusing on the practices, care, motives, and views of the press-especially when, as is likely for a case reaching trial, the story is false-thus invite punishment of the press. ${ }^{65}$ A good trial lawyer will be able to paint the dispute as a contest between good and evil, but the necessary evidence to prove reckless disregard leaves no doubt which side is evil. Thus, the average jury award in the 1980s in cases where reckless disregard was found exceeded $\$ 2$ million. 66

It does not reduce the chill on newspapers to learn that few plaintiffs get to keep their awards and that the average successful plaintiff receives a mere

57. Gertz v Robert Welch, Inc., 418 US 323, 342-43 (1974).

58. Philadelphia Newspapers y Hepps, 475 US 767, 776 (1989).

59. Milkovich v Lorain Journal, 110 S Ct 2695, 2706 (1990), quoting Hustler Magazine v Falwell, 485 US 46, 53-55 (1987).

60. See Bose Corp. v Consumers Union, 466 US 485, 511 (1984).

61. Powe, The Fourth Estate at 121, 134 (cited in note 7); see also David A. Anderson, Is Libel Law Worth Reforming?, 140 U Pa L Rev 525 (1991).

62. Powe, The Fourth Estate at 119 (cited in note 7).

63. Defense lawyer Robert Sack aptly notes that the "few plaintiffs who succeed resemble the remnants of an army platoon caught in an enemy crossfire. Their awards stand witness to their good luck, not to their virtue, their skill or the justice of their cause." Randall Bezanson, Gilbert Crandell \& John Soloski, Libel Law and the Press 199 (Free Press, 1987).

64. Powe, The Fourth Estate at 120 (cited in note 7).

65. Id at 125-27.

66. Id at 127; Anderson, $140 \mathrm{U} \mathrm{Pa} \mathrm{L} \mathrm{Rev} \mathrm{at} 514$ (cited in note 61). 
$\$ 20,000.67$ There seems to be a damages explosion in tort verdicts generally, and newspapers know catastrophe can arrive with just one huge verdict, such as the $\$ 9$ million judgment against the Alton (Illinois) Evening Telegraph, which sent the newspaper to bankruptcy court (although a subsequent settlement allowed the 38,000-circulation newspaper to stay in business). ${ }^{68}$ What makes defamation a special tort is that the injury that plaintiffs suffer seems far less severe than a physical injury to a tort plaintiff. Large jury verdicts, both punitive damages and those for emotional pain and suffering, are designed more to punish than to compensate. ${ }^{69}$

The operation of New York Times thus has produced a strange landscape. Issues of truth and falsity rarely surface, and reputations are not cleared for the vast majority of plaintiffs. For those few that get to a jury, however, trying the press can lead to a large, albeit only momentary, windfall. The possibility of that windfall, coupled with the necessary legal fees to avoid it, maintains a chilling effect on the press even though appellate supervision typically cuts the amounts of the verdicts considerably. Libel law, having been wholly remade in the wake of New York Times, needs to be rethought again.

It is not that the Court misunderstood what to balance; rather, its rules systematically undermine all the values it attempts to protect. Instead of attempting to make constitutional doctrine evermore intricate as it faced the inevitable array of common law rules of defamation, the Court should have remembered the balance with which it began. ${ }^{70}$ When newspapers print defamatory falsehoods, they cause harm that is wholly divorced from the standard of care. From the perspective of the public generally, there can be no doubt that the newspaper is more at fault when it publishes with actual malice, but the plaintiff's reputation is harmed exactly the same even if the paper published without the slightest fault. Simply, the fault standard is aimed solely at protecting the press and public from the effects of selfcensorship. It necessarily results in undervaluing reputation. We know there is harm and we know who caused it; with less certainty, but nevertheless reasonable assurance, we also know the body politic is ill-served both by false information and by the chilling effect the libel rules have on the decision to enter public life. Reputation cannot be served by increased numbers of rules that both make it more difficult for plaintiffs to get to juries and push truth further from the central aspect of a trial.

Conversely, press and public interests cannot be served as long as damage verdicts can go through the sky. Gertz v. Robert Welch, Inc. stated compensation without injury was unconstitutional, but it left glaring loopholes open with both punitive damages and compensation for mental anguish (a harm that flows by definition from libel)..$^{71}$

67. Bezanson, Crandell \& Soloski, Libel Law and the Press at 178 (cited in note 63).

68. See Green v Alton Telegraph Printing Co., 107 Ill App 3d 755, 438 NE2d 201 (1982); Rodney Smolla, Suing the Press 74 (Oxford U Press, 1986).

69. Powe, The Fourth Estate at 121-24, 126-27, 130-31 (cited in note 7).

70. Gertz, 418 US at 342-43; Powe, The Fourth Estate at 136 (cited in note 7).

71. Gertz, 418 US at $349-50$. 
A central problem of libel is that there is no rational way for the parties to calculate how much a case is worth. ${ }^{72}$ While it is inconceivable to think of a person harmed by words to be damaged in excess of $\$ 1$ million for mental anguish, that is how the rules allow juries to assess damages-even though Gertz had purported to limit damages to injury. The lottery nature of the few large winners and the loss sustained by the few large losers is then compounded by the fact that punitive damages are inevitable if the New York Times actual malice standard is met. ${ }^{73}$ When the potential recovery is unlimited, both sides are likely to spend more in litigation costs than the case is actually worth. Realistic damages would limit defense spending, the single largest factor in libel costs, and thereby serve well as a means of reducing the chill of litigation. Bringing reality to damages, coupled with an end to the actual malice requirement-thereby allowing juries to find truth rather than wrongdoing by an arrogant and seemingly unchecked defendant-could restore the balance that New York Times articulated and serve both the public and the press.

\section{Privacy}

The dignity tort of invasion of privacy by publication, from its inception by Warren and Brandeis ${ }^{74}$ to protect Warren's gala dinner parties from public view, ${ }^{75}$ to the present, appeals more to the affluent than other segments of society. Privacy has never done as well in the courts as in the legal journals. Typically, for recognition, privacy must combine with a second value of some importance. The need for second chances for middle class juvenile offenders or the stigma associated with being raped are currently popular second values. Even in these situations, the harms from disclosure may be insufficient to override the public interest in accurate information.

When the Miami Herald trailed Gary Hart and Donna Rice to Hart's Georgetown townhouse and then published what it purported to find, no potential lawsuit was mentioned. There was an ethical debate about both the Herald's tactics and its choice to publish the article, but the public had no doubt about the relevancy of the information. Hart's frontrunning candidacy was over. He may have had, as he kept protesting, the best ideas for leading the nation, but voters wanted nothing more of him. Because some voters would undoubtedly find any information relevant to the decision of whether to elect public officials, it would be shocking if the Court recognized any privacy interest on such officials' behalf.

When one shifts from public officials to private individuals, the balance also shifts, but even here the Court has always protected the press in its publication of legally acquired information. Thus, in Florida Star v. B.J.F., ${ }^{76} \mathrm{a}$

72. Anderson, $140 \mathrm{U}$ Pa L Rev at 515 (cited in note 61).

73. Id at 514; Powe, The Fourth Estate at 124 (cited in note 7).

74. Louis Brandeis \& Samuel Warren, The Right to Privacy, 4 Harv L Rev 193 (1890).

75. Don Pember, Privacy and the Press 23 (U Washington Press, 1972).

76. 491 US 524, 532-36 (1989). 
civil privacy case, the Court set aside a damages award for negligent publication of a rape victim's name because the newspaper had lawfully obtained the information through government disclosure. The Court recognized, as it had previously, that the state is in the best position to protect against disclosure through careful internal procedures. Yet, as Smith v. Daily Mail Publishing 77 shows, even careful internal procedures cannot prevent a newspaper from acquiring information about public crimes, such as that newspaper did when one junior high school student murdered a classmate in school. The Court offered a pair of rationales in protecting the paper, essentially relegating the child's privacy interest. As with Florida Star, however, the Court left open the possibility that on other facts that privacy interest might prevail.

Florida Star and Smith may be usefully contrasted with Seattle Times $v$. Rhinehart, ${ }^{78}$ where the Court held that information acquired by the press in state-mandated discovery for litigation cannot be published unless the information actually comes out in the litigation. Rhinehart's balance demonstrates that there are some circumstances where it is too unfair to allow the press to publish (without sanction) information it possesses. Perhaps one may extrapolate from Rhinehart that if the press broke into property and pillaged files or planted eavesdropping devices, and later published, then the publication could also be penalized. Just as a second reinforcing value, such as the stigma associated with being a rape victim, may be necessary for initial state recognition of the privacy claim, so it appears that privacy will also need a second reinforcing interest, such as illegal acquisition, for its harm to be deemed sufficient to override the first amendment right to publish truthful information.

\section{E. Obscenity}

Ever since the Court held that obscenity and sexual explicitness are not synonymous, ${ }^{79}$ it has been baffled by two related, but largely unanswered, questions: What is obscene, and why? The latter pertains directly to harm. The Court generally has found little or no credible research tying obscenity to legitimately regulatable harm. Recently, research has shown violent pornography may cause harm, ${ }^{80}$ but there is little correlation between violent pornography and the Court's definition of what is suppressible.

77. 443 US $97,104-06(1978)$.

78. 467 US 20, 37 (1984).

79. Roth y United States, 354 US 476, 487 (1957).

80. See Edward Donnerstein \& Leonard Berkowitz, Victim Reactions in Aggressive Erotic Films as a Factor in Violence against Women, $41 \mathrm{~J}$ Personality \& Soc Psychology 710 (1981); Neil M. Malamuth \& Edward Donnerstein, eds, Pornography and Social Aggression (Academic Press, 1984). Donnerstein's "work is frequently cited as evidence of pornography's negative social impacts." Margaret $H$. Thompson, Steven H. Chaffee \& Hayg H. Oshgan, Regulating Pornography, $40 \mathrm{~J}$ Communication 73, 74 (1990). A prime example is the so-called "Meese Commission" Report, the Attorney General's Commission on Pornography Final Report which states there is a link between sexual aggression and non-violent, but degrading, depictions of women. Attorney General's Commission on Pornography, Final Report 330 (US GPO, 1986)("Meese Commission Report”). Yet Donnerstein "has repeatedly 
If obscenity, but not necessarily sexual explicitness, is suppressible, then there must be some way to distinguish the obscene from the merely frank. Although Justice Stewart made himself an object of derision with his famous "I know it when I see it" 81 definition of hard core pornography as obscenity, the Court has not done much better in providing a definition. It essentially copied Stewart's position and established a policy of reversing obscenity convictions without offering justification for its practice. ${ }^{82}$ In attempting to define obscenity, whether in Roth, ${ }^{83}$ Memoirs, ${ }^{84}$ or Miller, ${ }^{85}$ the Court has fared little better because it is all but impossible to define a constitutional line with words that have lost their meaning (and probably were inherently vague before that). In the mid-1980s, the most helpful the justices could be in clarifying the meaning of obscenity was to state that it does not include materials appealing to a normal, as opposed to a shameful or morbid, interest in sex. ${ }^{86}$

The Court did not match its difficulties in definition with similar difficulties in explanation, largely because it rarely has tried to explain why obscenity could be proscribed. Indeed, until the 1980s' crusade against child pornography, the Court's explanation for why obscenity may be proscribed has never matched the reasons offered by the proponents of suppression. ${ }^{87}$ Nor can the Court take much credit for its one correct match regarding child pornography, since most controversies about regulating obscenity have nothing to do with children. One rationale offered for the regulation of obscenity was that it is $\sin ^{88}$ In a companion case to Miller, ${ }^{89}$ the Court offered a vague "quality of life" rationale that could apply to everything or nothing. More recently, when radical feminists decided that pornography was

\footnotetext{
stressed that sexually explicit films have undesirable effects only when sex is mixed with violence." Thompson, Chaffee \& Oshgan, Regulating Pormography at 74 (cited in this note)(emphasis added). Donnerstein, who had testified to the Meese Commission that there were no studies linking aggressive behavior and non-violent pornography, reacted to the contrary conclusions of the Commission by labelling them "bizarre." Philip Shenon, A Second Opinion on Pormography's Impact, NY Times 4-8 col 3 (May 18, 1986). As Dr. Judith Becker, an associate professor of clinical psychology at Columbia University, noted in her dissent from the Commission's conclusions, they were attempting "to tease the current data [which did not deal with non-violent depictions] into proof of a causal link [and this] simply cannot be accepted." Meese Commission Report at 204 (cited in this note).

81. Jacobellis v Ohio, 378 US 184, 197 (1963)(Stewart concurring).

82. Redrup $v$ New York, 386 US 767 (1967); Miller $v$ Califormia, 413 US 15, 22 n3 (1973)(Court began practice of summarily reversing convictions when majority of members, applying separate tests, found first amendment protection).

83. 354 US at $487-91$.

84. A Book Named "John Cleland's Memoirs of a Woman of Pleasure" v Massachusetls, 383 US 413, 418. 20 (1966).

85. 413 US at $23-26$.

86. Brockett v Spokane Arcades, 472 US 491, 498 (1985).

87. New York v Ferber, 458 US 747 (1982).

88. Louis Henkin, Morals and the Constitution: The Sin of Obscenity, 63 Colum L Rev 391 (1963).

89. Paris Adult Theater I slaton, 413 US 49, 58 (1973).
} 
patriarchy, and convinced cities to agree by passing legislation prohibiting it, the Court sacked their handiwork without even hearing oral argument. ${ }^{90}$

The Court can neither define obscenity nor offer a rationale for its suppression. Does it cause sin or is it sin? Does it cause exploitation and domination of women or is it the exploitation and domination of women? Does it cause societal blight or is it a societal blight? Those who would regulate obscenity are sure of the answers (although they would disagree with each other), while those who are skeptical await some credible explanation and perhaps evidence of harm. The Court, hiding behind the last refuge of its discredited Chaplinsky ${ }^{91}$ approach, whereby expression deemed outside the first arnendment can be regulated for any or no reason at all, is unlikely to require answers. As a result, obscenity, which causes less demonstrable harm than the other areas surveyed above, can nevertheless be regulated far more extensively.

While the harms from obscenity are more diffuse and vague than those coming from national security breaches, invasions of privacy, or defamation, the Court has perceived that the benefits from borderline obscenity cases are equally diffuse and vague, and maybe even nonexistent. ${ }^{92}$ Greenmoss Builders, ${ }^{93}$ a libel suit involving an erroneous credit report, took a similar approach. It is conceivable, then, that a compelling case of invasion of privacy, without any attempt to link it to a public issue, might receive like treatment. However, in both libel and privacy, the Court begins with the assumption that the expression has value.

Sexual expression is viewed differently. Although lacking empirical proof of harm, those who would suppress it have substituted the fervor of certainty. The Court's line-drawing has been consistently questioned by various local government units operating on the view that, the Court to the contrary notwithstanding, they should suppress frank descriptions and depictions of sex. There has been a thirty-year guerrilla war between the Court and those disagreeing, where the latter have devoted considerable efforts to breaking the Court's boundaries and chilling, if not stifling, materials that the Court would protect. While the Court's response has been mixed, it has recognized frontal attacks on its position for what they are. Thus, both Georgia's attempt to label the critically-acclaimed movie Carnal Knowledge as hard core pornography ${ }^{94}$ and Indianapolis's effort to rid its marketplace of all sexual materials that were unacceptable to radical feminists or fundamentalist

90. American Booksellers Assoc., Inc. v Hudnut, 771 F2d 323 (7th Cir 1985), aff'd, 475 US 1001 (1986)(definition of pornography in ordinance as graphic sexually explicit subordination of women, and reference to particular depictions, violated first amendment).

91. Chaplinsky $v$ New Hampshire, 315 US 568, 572 (1942)(there are well-defined and narrowly limited classes of speech, the prevention and punishment of which do not raise any constitutional problem).

92. Renton v Playtime Theaters, 475 US 41 (1986); FIY/PBS, Inc. v Dallas, $110 \mathrm{~S} \mathrm{Ct} 596,617$ (1990)(Scalia dissenting).

93. Dun E Bradstreet v Greenmoss Builders, 472 US 749 (1985).

94. Jenkins v Georgia, 418 US 153 (1974). 
ministers were invalidated. ${ }^{95}$ When local governments have attempted to reach materials that have substantive content in addition to an emphasis on sex, the Court has successfully blocked their efforts. Thus, despite strong local challenges to its policy regarding sexual expression, the Court has confirmed its position by striking those attempts that unmistakably cross the line of permissible regulation.

\section{Regulating Market Power}

In Buckley $v$. Valeo, ${ }^{96}$ the Court's initial campaign finance decision, the Court stated that "the concept that government may restrict the speech of some elements of our society in order to enhance the relative voice of others is wholly foreign to the First Amendment ...."97 Were that statement accurate, this would be a very short section. While it is entirely accurate for newspapers, it is almost as inaccurate for broadcasting. The statement is also no longer correct even in the area in which it was made.

\section{A. Newspapers}

Writing about the press after a three-year study during the mid-1940s, the Hutchins Commission, named after its chair, Robert Maynard Hutchins, stated that " $[\mathrm{t}]$ he right of free public expression has . . . lost its earlier reality." 98 Subsequent events only underscored this conclusion. The number of daily newspapers, which had been dropping throughout this century, has declined even further today. New daily newspapers in urban areas have proven financially impossible to sustain. Thus, most cities have become single newspaper monopolies, many of which, in turn, have been acquired by newspaper chains. Local competition has vanished and many observers believe diversity has diminished. ${ }^{99}$

The Miami Herald demonstrated the influence of market power by savaging a candidate for state representative in pre-election editorials and refusing to print his response, as a long-standing but unused state law required. ${ }^{100}$ The candidate, Pat Tornillo, lost the election and ascribed his defeat to the unfair intervention of the dominant newspaper and its refusal to allow him access, as required by law, to reach the voters in his district with a response putting the facts in perspective. ${ }^{101}$

Tornillo prevailed in the Florida Supreme Court, which linked the empirical reality of increased concentration of ownership of mass

\footnotetext{
95. Hudnut, 475 US 1001.

96. 424 US 1 (1976).

97. Id at $48-49$.

98. The Commission on Freedom of the Press, A Free and Responsible Press 16 (U Chicago Press,

99. Powe, The Fourth Estate at 201-03 (cited in note 7).

100. Miami Herald Publishing Co. v Tomillo, 418 US 241, 243 (1974).

101. L. A. Powe Jr., Tornillo, 1987 S Ci Rev 345, 367-72.
} 1947). 
communications to a public service theory of the press. The Court stated that "[f]reedom of expression was retained by the people through the First Amendment for all the people and not merely for a select few." 102 Public debate could not be left entirely in the hands of "just those who have invested money in the publishing business." 103 Whatever rights a newspaper has to initiate discussion about an electoral contest, once it has, the state can require that the discussion present both sides.

The Herald's behavior during Tornillo's candidacy was copied by the press nationally while the case was pending in the United States Supreme Court. Having both the willingness and the means to defend its prerogatives, the press wrote column after column, editorial after editorial, on the importance of reversing the Florida decision. ${ }^{104}$ Materials supporting the Florida decision and the right of reply never entered the public debate, however, because the media had an interest in suppressing them. While this may have kept the public appropriately informed in the eyes of the press, briefs and oral argument told the Court both sides of the controversy. After agreeing with the reality of newspaper concentration, the Court nevertheless sustained the press position. The right to reply law was found unconstitutional because it would chill the newspaper's willingness to enunciate its views and because the Constitution places editorial choice in the hands of press editors. ${ }^{105}$

Tormillo guarantees that a major publication in the marketplace cannot be toned down or made to cover specific issues, even if it is spending too much time on one side of one issue or covering certain issues insufficiently. In a test of the idea that the marketplace can be made better by modest regulation, the Court disallowed the experiment. Yet this result was hardly surprising. Freedom of the press had always meant lack of regulation. What had changed was the nature of the industry combined with the alluring analogy of broadcast regulation. Broadcast regulation had made print regulation thinkable.

\section{B. Broadcasting}

From broadcasting's very inception, Congress, regulators, and the Court believed that it was not entitled to the constitutional protections accorded the print media. ${ }^{106}$ Ultimately, the constitutional status of broadcasting has presented the Court with two questions: first, whether there is a relevant constitutional distinction between broadcasting and print; and, second, if there is a distinction, whether a different and appropriate first amendment theory is available for application. In $N B C v$. United States, ${ }^{107}$ the Court held that there is a constitutional distinction; then, reaffirming its $N B C$ holding, the

102. Tornillo v Miami Herald Publishing Co., 287 So2d 78, 83 (Fla 1973).

103. Id at 91 .

104. Powe, The Fourth Estate at 270-71 (cited in note 7).

105. Tornillo, 418 US at 257-58.

106. Powe, American Broadcasting and the First Amendment at 13-30 (cited in note 2).

107. 319 US $192(1943)$. 
Court elaborated its view of appropriate constitutional theory for analyzing broadcasting cases in Red Lion Broadcasting v. FCC. ${ }^{108}$

The Court's conclusion that there is a constitutional distinction between broadcasting and print is based on the familiar assumption that broadcasting is an inherently scarce resource. ${ }^{109}$ Necessarily implicit in this conclusion is the proposition that print is not an inherently scarce resource. Not surprisingly, the Court has not explained why land, ore, trees, or newsprint are not scarce resources while the electromagnetic spectrum is. All are limited; none can be multiplied except over time. Nor has the Court noted that for almost the entire twentieth century, the number of daily newspapers has been on a steady decline ${ }^{110}$ while the number of broadcast outlets has been increasing constantly and sometimes dramatically, as seen on the day the Federal Communications Commission ("FCC") created 684 new frequency modulated ("FM") stations in 48 states."11

Instead of looking at the facts, the Court has taken refuge in theory. Based on the events of the 1920s, it assumed initially that without regulation there would be chaos because too many people would broadcast on the same frequency and no one could be heard.112 However, that confused the necessity to space broadcasters via a property rights mechanism with the need to regulate their speech. After all, if everyone wrote on the same piece of paper, it too would be unintelligible. The Court later asserted that more people want broadcast licenses than can have them.113 However, it never paused to note that the reason for the excess demand is that broadcast licenses are highly valuable yet given away at no cost. If newspapers were given away gratuitously, there would also be more individuals wanting them than could have them. The Court's assertion of scarcity is simply silly. While scarcity may have made sense a half-century ago, few, outside of the Supreme Court justices, have taken it seriously in years. ${ }^{114}$

Furthermore, the Court never explains why scarcity matters. If one assumes that the justices know better, as Tormillo suggests they may, then clinging to the scarcity argument might make sense so long as the purpose is to authorize regulation of those means of communication that are more powerful than print. Essentially the Court has authorized an updated copying of the Tudor-Stuart response to the introduction of the printing press, which was to try to domesticate it by bringing print under royal prerogative. ${ }^{115}$ If broadcasting is also perceived as potentially destabilizing, then its regulation can be supported for similar reasons. Indeed, once power is substituted for

\footnotetext{
108. 395 US 367 (1969).

109. Powe, American Broadcasting and the First Amendment at 200 (cited in note 2).

110. Powe, The Fourth Estate at 201 (cited in note 7).

111. Powe, American Broadcasting and the First Amendment at 202 (cited in note 2).

112. $N B C, 319$ US at 212 .

113. Red Lion, 395 US at 388-89.

114. Daniel D. Polsby, Candidate Access to the .tir: The L'ncertain Future of Broadcaster Discretion, 198 I S Ct Rev 223, 258.

115. Frederick S. Siebert, Freedom of the Press in England: 1+76-1776. 21-301 (U Illinois Press, 1952).
} 
scarcity, broadcast regulation makes much more sense. ${ }^{116}$ Viewers and listeners choose what to hear everyday, from newspapers to books to street corner discussions to television. If broadcasting lacked power, the choice exercised daily by viewers and listeners would seemingly be a sufficient safeguard without the added governmental paternalism to protect listeners from broadcast programming they do not wish to hear. The sovereign prerogative of choice is ignored because of the specter of market failure, the necessity of corrective supervision, and the fear of unforeseen consequences.

That there is a constitutional distinction between broadcasting and print is most apparent in Red Lion's validation of the fairness doctrine, which requires broadcasters to give adequate coverage to significant public issues and to ensure that such coverage is fair in that it accurately presents conflicting views on those issues. ${ }^{117}$ The fairness doctrine encapsulated a journalistic code of ethics to which most reporters and publishers, in all media, profess allegiance. ${ }^{118}$ Nevertheless, as Tornillo held, the idea of fairness is enforced internally rather than by the legal system in all other media; for the nonbroadcast media, the first amendment mandates that the government leave issues of fairness to editors and readers, not to judges. Not so for the broadcast media. The Court has concluded here that the rights of viewers and listeners are paramount. Furthermore, because viewers and listeners cannot directly exercise their rights, a governmental body is necessary to supervise broadcasting and ensure that each speaker operates according to a governmentally designed public interest standard. Under the fairness doctrine, it is not a defense for a broadcaster to note the availability of the views at issue in either the print media or on other broadcast outlets. Rather, each broadcaster has an individualized duty to provide the necessary information in the public interest, even if that means replicating existing information and consequently denying the public alternatives. ${ }^{119}$

The fairness doctrine provided grounds for legal challenges to broadcasters who presented controversial programming. Even if the challenges ultimately failed, the questioning of editorial decisions where the law mandated an answer from the editor not only imposed costs in time and legal fees, but also carried the dim possibility of loss of license. ${ }^{120}$ There were no similar costs to a broadcaster for avoiding controversy. It is widely believed that that is exactly what some broadcasters did.121 While Red Lion denied the existence of a chilling effect, it also stated that if one existed the FCC could do something about it. ${ }^{122}$ Both statements fit the power rationale:

116. Powe, American Broadcasting and the First Amendment 210-15 (cited in note 2).

117. 395 US at 375-79.

118. Thomas G. Krattenmaker \& L. A. Powe, Jr., The Fairness Doctrine Today, 1985 Duke L J 151, 152-53.

119. Rep. Patsy Mink, 59 FCC2d 987 (1976); Brandywine-Main Line Radio v FCC, 473 F2d 16 (DC Cir, 1972).

120. Krattenmaker \& Powe, 1985 Duke $\mathrm{L} \mathrm{J}$ at $158-59$ (cited in note 118).

121. Id at 158 .

122. 395 US at 396. 
a chill on a destabilizing medium could be welcomed as a benefit, and government supervision of how broadcasters respond to the chill ensures that the response will not be too hot.

The Court rejected its traditional first amendment assumptions of consumer choice and inherent governmental partisanship and instead created new ones supposedly tailored to the nature of the medium and its supposed power. The Court assumed that by creating newly tailored constitutional doctrine it could make broadcasting "function consistently with the ends and purposes of the First Amendment." 123 Presumably, broadcasting otherwise would not so function. Had the Court succeeded, there might have been grounds for reconsidering the traditional first amendment assumptions in nonbroadcast contexts, and Tornillo could have gone the other way.

The traditional assumptions do apply to broadcasting. The first amendment theory for broadcasting created by the Court has resulted in partisan application of neutral regulations, allowed a chilling effect, and denied to viewers and listeners their supposedly sovereign right of choice. ${ }^{124}$ With the FCC's 1987 repeal of the fairness doctrine, which the Court let pass without review, ${ }^{125}$ the key underpinning of regulation limiting broadcast power has been removed. Because the Court never formally embraced power, using scarcity as a synonym instead, the Court can pretend the power theory never existed, and recognize the obsolescence of scarcity simply by announcing changed circumstances. Then, again, it need not do so; at least the swings in first amendment theory for campaign finance suggest it may not.

\section{Campaign Finance}

The framework of the debates on the constitutionality of various campaign finance reforms was in place before the Court decided Buckley $v$. Valeo. ${ }^{126}$ Reform has sought to limit contributions to candidates to prevent the purchasing of media access and the consequent appearance of impropriety, and to control the escalating cost of running for office. The primary cost of any campaign is the attempt to influence voters. For some, this fact is both the beginning and the end of the analysis: limiting money limits speech and is therefore unconstitutional. ${ }^{127}$ For others, there was a brief moment of denial that money had anything to do with what it was spent on and that therefore the first amendment, if applicable at all, was of only marginal interest. ${ }^{128}$ This denial was eliminated by Buckley. Since Buckley, proponents of reform have countered the simple first amendment view espoused by those opposing money limitations by arguing that some individuals are more prone to contributing to political campaigns than others, leading to too much speech of

123. Id at 390 .

124. See generally Powe, American Broadcasting and the First Amendment (cited in note 2).

125. Syracuse Peace Council v FCC, 867 F2d 654 (DC Cir 1989), cert denied, 110 S Ct 717 (1990).

126. 424 US 1 .

127. This was, and is, the ACLU position.

128. Buckley v Valeo, 519 F2d 821 (DC Cir 1975); J. Skelly Wright, Politics and the Constitution: Is Money Speech?, 85 Yale L J 1001 (1976). 
a certain viewpoint. These individuals unduly influence the debate, skewing the choice of candidates and the choice of policies supported by elected officials. Proponents point out that by limiting the amount of money that can be expended, campaign finance reform would limit the market power of these individuals and enhance that of others less inclined to contribute to political campaigns. Proponents argue that it is, therefore, only appropriate to give deference to legislative solutions capping contributions and expenditures. ${ }^{129}$

In many respects Buckley split all the major differences. It erected a rigid constitutional distinction between contributions and expenditures. A contribution could be regulated because it could lead to an appearance (and reality) of corruption of the process. Candidate expenditures could not be regulated because the only real interest in limiting them was to limit speech since candidates could not corrupt themselves. The same held true for individual expenditures not coordinated through a campaign. The Court understood that an entirely new meaning of freedom of speech would have to be established to criminalize a quarter-page ad placed by an individual in a major newspaper stating, "Gerald Ford pardoned Richard Nixon, Vote for Jimmy Carter." Thus the Court held, "the concept that government may restrict the speech of some elements of our society in order to enhance the relative voice of others is wholly foreign to the First Amendment." 130

Subsequent cases added twists to this approach, namely that ballot initiatives presented pure speech issues and corporations presented problems. Both were present in First National Bank of Boston v. Bellotti, ${ }^{131}$ where Massachusetts attempted to limit corporate spending on a personal income tax initiative. Quoting Buckley, the Court again rejected the idea of leveling down ${ }^{132}$ and held that precluding corporations from entering the public debate was unconstitutional. Subsequently, the Court's position that corruption was not a potential danger in non-candidate circumstances was underscored by striking down an effort in Berkeley, California to prevent landlords from attempting to purchase too many ads about rent control. ${ }^{133}$

The Court's most recent foray into campaign finance, Austin v. Michigan Chamber of Commerce, ${ }^{134}$ challenges several seemingly established points. The Chamber, a nonprofit corporation funded by annual dues from member businesses (three quarters of which are for-profit corporations), wished to place a newspaper ad in favor of a specific candidate for the state house of representatives. The funding was to be independent of the candidate's campaign. Had the Chamber been a media organization, there would have

129. Daniel H. Lowenstein, Campaign Spending and Ballot Propositions: Recent Experience, Public Choice Theory and the First Amendment, 29 UCLA L Rev 505 (1982); Buckley, 424US at 257 (White concurring and dissenting separately); First National Bank of Boston v Bellotti, 435 US 765, 802 (White dissenting).

130. Buckley, $424 \mathrm{US}$ at $48-49$.

131. 435 US 765 (1978).

132. Id at 790-91, quoting Buckley, 424 US at 48-49.

133. Citizens Against Rent Control v Berkeley, 454 US 290 (1981).

134. 110 S Ct 1391 (1990). 
been no question of its right to present its views fully; ${ }^{135}$ similarly, had it been an individual, Buckley guaranteed the right to do so. Since the Chamber was neither a media organization nor an individual, however, it had no such right. Under Michigan state law, corporations are prohibited from using general treasury funds in connection with candidate elections. The legislature feared that allowing access to corporate treasuries would create an appearance of corruption in the electoral process. In a retreat from its Bellotti decision, the Court agreed.

In Bellotti, the Court had held that it was irrelevant that the speaker was a corporation so long as the corporation's message was protected speech. However, in Austin it found that it was relevant that the speaker was a corporation, even if its message was protected speech. Austin held that a state could prevent a corporation from speaking; to that extent, Bellotti is overruled. Under Austin, a corporation may be precluded from saying what an individual may say freely. However, that is hardly the most interesting aspect of the decision; instead, we must look at what the Court has to say about the state's rationale and power in the marketplace of ideas.

The rationale for Michigan's prohibition was to prevent actual corruption or the appearance of corruption in the electoral process, but for the Court, the latter was sufficient. ${ }^{136}$ Finding that the prohibition had been appropriately narrowly tailored, the Court found this interest compelling, ${ }^{137}$ thus softening its notion of compelling interest. It allowed the requirement of strong probabilities of harm to fade into possible misperceptions of harm. But the Court did not stop at having watered-down the level of state interest required for restricting speech. More significantly, the Court appears to have concluded that limiting the impact of money on debate is, itself, a compelling state interest. If this is an accurate interpretation, then the limited reading of Austin as only undermining Bellotti must yield to a more general undermining of Buckley.

The Court wrote that Michigan was targeting "a different type of corruption."138 The legislature wished to prevent the "distorting effects of immense aggregations of wealth that are accumulated with the help of the corporate form and that have little or no correlation to the public's support for the corporation's political ideas." 139 This may be another way of saying that Charles Lindblom was right in Politics and Markets 140 and that corporations had been given too much in Bellotti. But, while "corporation" appears twice in the sentence, ${ }^{141}$ the language is more general. The sentence makes perfectly good sense without "corporation," and there is no logical

135. Tornillo, 418 US 241.

136. Austin, $110 \mathrm{~S} \mathrm{Ct}$ at 1397.

137. Id at 1398 .

138. Id at 1397.

139. Id.

140. Charles E. Lindblom, Politics and Markets: The World's Political-Economic Systems (Basic Books, 1977)

141. Austin, $110 \mathrm{~S} \mathrm{Cl}$ at 1397. 
reason why it must be limited to corporations. The Court's real conclusion is that too much money distorts debate. It does not matter whether the money comes from a corporation, inherited wealth (typically amassed through corporations), hard work, luck, or undetected insider trading.

If someone with money wishes to spend it to persuade others to agree with her positions, the "distorting" effects as well as the lack of correlation with public support remain identical to those that would result from the Chamber's spending. The Court's statement tying speech into preexisting support is even more troublesome because it suggests that, before money can be used for speech, the speech must correlate with what the public already believes. What other plausible meaning could there be for the tying of distortion into public support for political ideas? If the Chamber's candidate loses, then there would be evidence of lack of support of the Chamber's views. But who would care? It is only if the Chamber's candidate wins that problems arise. Does victory validate correlation between the Chamber's views and those of the body politic? Or would the victory mean that the Chamber had successfully distorted the election with its ads? I assume it is the latter, and by now the Court's definition of distortion is relatively clear: distortion seems remarkably close to persuasion. Speech that changes views distorts and therefore may be stopped. An old charge directed at the clear and present danger test was that it stopped speech just as it was going to be effective in leading to action. ${ }^{142}$ Here, speech is stopped because it might be effective in changing views. The motto for this approach may be described as "long live the status quo."

Newspapers, however, can communicate as much and as freely as they wish, even if the public does not share their views and even if they are organized as a corporation. The Michigan law exempted them, as mandated by Tornillo. Yet after Austin, Tormillo could be reconsidered emphasizing the Miami Herald's distorting effect on the Miami voters who need not share their dominant paper's views. I strongly doubt, however, whether there is reason to believe the Court would intend anyone to take its logic seriously.

\section{IV}

\section{Conclusion}

Although its results are relatively clear, the Court has eschewed final bright-line rules in dealing with each type of harm. The Court never settled the national security publication problem and may not see the problem again for years with the Cold War having ended. It has always discussed the harm more than the redress for its infliction in privacy cases. Because the information published in privacy cases is often relevant to some public issue, the problem is likely to remain more ethical than legal. The Court has shown no signs of changing its active libel intervention, which adds a complex constitutional overlay to an already intricate web of common law rules. The

142. Thomas I. Emerson, The System of Freedom of Expression 16 (Random House, 1970). 
area begs for simplification and rationalization on verdicts, but it may prove in no one's interest to push for change. Attorneys on both sides benefit from the present system, and the press itself has probably learned to live with, and insure under, the regime.

Libel and obscenity are different. Obscenity law has changed less over the past two decades than societal attitudes. Although society now appears willing to tolerate more restrictive legislation, the Court has made little change in the law. Regardless of how receptive the Court will be, it allows most regulation in this area to prevent harm even though the evidence of actual harm is soft in comparison with other areas.

While initially done sub silentio in broadcasting, regulating to achieve some market balance has become an integral part of the legal regime under which mass communications function. Yet, once the Court starts down the road of allowing regulation for balance, Tornillo creates an inherent instability insofar as it leaves one very large market participant free to communicate as much as it pleases: newspapers. If a person like William Loeb must always be able to influence significantly the selection of the two presidential nominees because of his ownership of the Manchester $(N H)$ Union-Leader, it is difficult to explain why Democrats, for example, ought to be limited in the information they wish to circulate for the New Hampshire primary. ${ }^{143}$ Yet, after nearly two decades of campaign finance regulation, the reformers have never discussed how the press fits in the overall picture and what sense it makes to limit all but the largest participants. ${ }^{144}$

There is little doubt that a major intellectual impetus for campaign regulation is the correct belief that the wealthy should not be able to use their money as a surrogate for buying votes. Furthermore, the area may well represent the entry-pushing wedge of Carolene Products' footnote four analysis to the first amendment. ${ }^{145}$ While footnote four's academic imperative to protect the insufficiently protected was sweeping through the fourteenth amendment, the first amendment remained impermeable. Footnote four had expressly excluded it, and given the love of the. first amendment by those academics writing about it, one could hardly expect to see exceptions being advocated. ${ }^{146}$ But as the wealthy acquire seemingly undue influence in debate and the ignorant rekindle hate speech, the idea that all speakers should be treated equally has come under question. ${ }^{147}$ Footnote four offers an easy answer: when in doubt, allow restraint of the powerful but protect the disadvantaged. ${ }^{148}$

143. L. A. Powe Jr., Mass Speech and the Newer First Amendment, $1982 \mathrm{~S} \mathrm{Ct} \mathrm{Rev} \mathrm{243,} 268$.

144. Sanford Levinson, Electoral Regulation, 18 Hofstra L Rev 411, $412-13$ (1989).

145. United States v Carolene Products, 308 US 144, 152 n4 (1938).

146. John Hart Ely, Foreword: On Discovering Fundamental Values, 92 Harv L Rev 5, 14-15 (1978). If the first amendment protects only "discrete and insular minorities," then we need to reconsider not only the entire concept of freedom of the press, but the history of the Sedition Act of 1798 (which under such an interpretation would be constitutional) as well.

147. Matsuda, 87 Mich L Rev 2320 (cited in note 6)

148. The sentence in text was written before publication of Julian N. Eule, Promoting Speaker Diversity: Austin and Metro Broadcasting, 1990 S Ct Rev 105, which imaginatively intertwines Austin 
Campaign finance reform, just like the fairness doctrine, gets a lot of mileage out of its name. The fairness doctrine has not been fair and legislation offered as reform is not necessarily beneficial. The soothing sounds of labels are poor substitutes for realities. When the Court allows the legislature to determine that too much speech about an election campaign is against the public interest-at least too much if a corporation is the one trying to get the messages to the public-it may be less of a footnote four oriented legislature protecting the disadvantaged than precisely what footnote four warned against: use by those in political power to protect themselves against the possibility of losing a future election. ${ }^{149}$

The mass communications cases have not only dealt with real harms, but have also put into play the Court's traditional first amendment assumption that even benign regulations of expression will afford partisan application. Where the mass communications cases track the speech cases, as they do when attempting to deal with harms caused by expression, they are closely aligned even if some solutions could be improved. Where they split from the speech cases and the assumption is relaxed, as in the broadcasting cases, ${ }^{150}$ they have thus far generated results more consistent with the traditional assumption than the better world called for by the limiting regulation. The area might gain some intellectual coherence by a frontal infusion of footnote four, removing the cloak of benignness, and articulating why some speakers should be toned down because their ideas have either too much or too little support. Such an infusion hardly seems an encouraging prospect if this is, indeed, what the future holds.

and the FCC's minority preference policies with a footnote four analysis that is free from the doublespeak that often accompanies the idea of promoting speech through quieting some. See also note 147 .

149. Eule aptly states: "Political reality suggests that legislative pursuit of speaker diversity will be rare. The American experience with speech infringements is stocked with attempts to suppress dissent, not with efforts to promote it." $1990 \mathrm{~S} \mathrm{Ct} \mathrm{Rev}$ at 126 (cited in note 148). I agree fully, indeed more so. The FCC's minority preference policies, sustained in Metro Broadcasting v FCC, $110 \mathrm{~S}$ Ct 2997 (1990), were almost unique in their efforts to promote diversity by adding, rather than subtracting, voices. And footnote four itself tells us this should be so. After all, if a group can persuade the legislature to assist it, in what sense can the beneficiaries be classified as politically powerless? Consider the other example of giving speech rights, Regan $v$ Taxation with Representation, 461 US 540 (1983), where a "public interest" organization argued that it was denied fifth amendment equal protection because it could not maintain tax exempt status while lobbying for its causes, but veterans groups could. Just what is it about veterans groups that allows them and them alone to maintain IRS charitable status while engaging in substantial lobbying activities? Is it because they are politically powerless? Or is it because, like minorities in the late-1980s (when Congress forbid the FCC to reconsider its minority preferences), it has a fair amount of legislative clout on the issue?

Not only do I believe that a grant of added rights is more likely to reflect political clout than powerlessness, I also think that the typical case will be, like Austin, one where the legislature decides to harm one group as a (n ostensible) way of helping another. It may well be that corporate interests speak too much and have too much legislative clout, but I would be far more impressed by the Michigan legislature if it attempted to finance all campaigns at a decent level of funding rather than deciding that certain interests ought not be allowed to take out newspaper ads because if they do so they may persuade voters to vote in a way they ought not.

150. See, for example, Red Lion, 395 US 367; see generally Powe, American Broadcasting and the First Amendment at 108-90 (cited in note 2). 